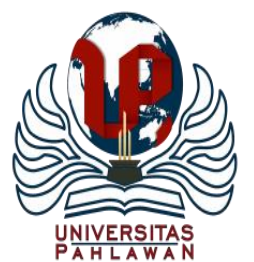

Jurnal Basicedu Volume 4 Nomor 4 Tahun 2020 Halaman 1044-1051

JURNAL BASICEDU

Research \& Learning in Elementary Education

https://jbasic.org/index.php/basicedu

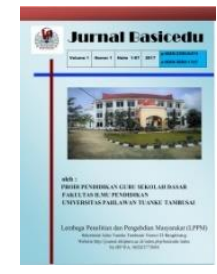

\title{
Efektivitas Model Pembelajaran Problem Based Learning Ditinjau dari Kemampuan Pemecahan Masalah Matematika di Sekolah Dasar
}

\author{
Bagoes Pradana Sapoetra ${ }^{1}$, Agustina Tyas Asri Hardini ${ }^{2}$ \\ Universitas Kristen Satya Wacana, Jawa Tengah, Indonesia ${ }^{1,2}$ \\ E-mail : $\underline{\text { bagoespradanasapoetra@gmail.com }{ }^{1}}$ agustina.hardini@ $\underline{\text { uksw.edu }}{ }^{2}$
}

\begin{abstract}
Abstrak
Tujuan penelitian ini untuk mengetahui efektifitas model pembelajaran Problem Based Learning terhadap keterampilan berpikir kritis siswa pada pembelajaran matematika di kelas IV semester I. Penelitian ini, metode penelitian yang digunakan adalah metode Pre Experimental Design. Subjek penelitian adalah siswa kelas IV SDN Barukan 2 dengan jumlah 20 siswa. Berdasarkan hasil analisis pre-test dan posttest menunjukkan bahwa kemampuan pemecahan masalah siswa pada menjadi lebih baik dengan menggunakan model pembelajaran Problem Based Learning pada saat pembelajaran berlangsung dibandingkan dengan nilai pretest yang tidak disertai dengan pemberian treatment, didapatkan nilai rata-rata pretest sebesar 72,2 sedangkan pada posttest didapatkan nilai rata-rata sebesar 80,2. Dengan demikian telah terbukti bahwa model pembelajaran Problem Based Learning efektif untuk meningkatkan keterampilan pemecahan masalah siswa dan mata pelajaran matematika.
\end{abstract}

Kata kunci: keterampilan pemecahan masalah, matematika, problem based learning

Abstract

The purpose of this study was to determine the effectiveness of the Problem Based Learning model for students' critical thinking skills in mathematics learning in class IV semester I. This study, the research method used is the method of Pre Experimental Design. The subjects of the study were the fourth grade students of SDN Barukan 2 with a total of 20 students. Based on the results of the pre-test and posttest analysis, it shows that the students' problem-solving ability is better by using the Problem Based Learning learning model when learning takes place compared to the pretest score that is not accompanied by treatment, the pretest average value is 72.2 while the posttest obtained an average value of 80.2. Thus it has been proven that the Problem Based Learning model is effective for improving students' problem solving skills and mathematics subjects.

Keywords: problem solving skills, mathematics, problem based learning

Copyright (c) 2020 Bagoes Pradana Sapoetra, Agustina Tyas Asri Hardini

$\square$ Corresponding author :

Address : Universitas Kristen Satya Wacana

Email : bagoespradanasapoetra@gmail.com

ISSN 2580-3735 (Media Cetak)

Phone : -

ISSN 2580-1147 (Media Online)

DOI: https://doi.org/10.31004/basicedu.v4i4.503 
1045 Efektivitas Model Pembelajaran Problem Based Learning Ditinjau dari Kemampuan Pemecahan Masalah Matematika Siswa di Sekolah Dasar - Bagoes Pradana Sapoetra, Agustina Tyas Asri Hardini

DOI: https://doi.org/10.31004/basicedu.v4i4.503

\section{PENDAHULUAN}

Pendidikan masih menjadi salah satu masalah penting di negara ini. Proses pembelajaran yang menekankan pada potensi peserta didik dinilai masih belum maksimal. Dalam proses pembelajaran seharusnya peserta didik dilibatkan secara langsung sehingga peserta didik dapat mengembangkan pengetahuan, daya berpikir dan kemampuannya secara maksimal. Menurut Sanjaya (2011: 1) salah satu masalah yang dihadapi dunia pendidikan kita adalah lemahnya proses pembelajaran, dimana peserta didik kurang didorong untuk mengembangkan kemampuan berpikir. Pengetahuan, daya pikir dan kemampuan menjadi bekal keterampilan peserta didik yang dapat digunakan untuk jenjang yang lebih tinggi dan untuk penerapan dalam kehidupan sehari-hari. Kurikulum pada tingkat pendidikan sekolah dasar (SD) menekankan bagaimana mendidik peserta didik untuk pemecahan masalah agar memiliki kompetensi untuk bekerja sama, memahami potensi diri, meningkatkan kinerja dan berkomunikasi secara efektif dalam pemecahan masalah.

\section{Berdasarkan Lampiran Permendikbud} Nomor 59 Tahun 2014, Matematika adalah ilmu universal yang berguna bagi kehidupan manusia, mendasari perkembangan teknologi modern, berperan dalam berbagai ilmu, dan memajukan daya pikir manusia. Salah satu ilmu pembelajaran berperan penting dalam kehidupan sehari-hari adalah pembelajaran matematika. Pembelajaran Matematika diharapkan mampu membekali peserta didik dengan keterampilan dan kemampuan menghadapi berbagai permasalahan matematika maupun dalam kehidupan sehari-hari.

Permasalahan yang dihadapi oleh guru matematika yaitu kesulitan peserta didik dalam pembelajaran matematika. Kesulitan tersebut antara lain kesulitan dalam pemahaman konsep, pemecahan masalah (mathematical problem solving), penalaran matematika (mathematical reasoning), koneksi matematika (mathematical connection), penerjemahan soal cerita, komunikasi matematika (mathematical communication), dan lain-lain. Pembelajaran matematika seringkali dianggap sebagai mata pelajaran yang menakutkan oleh peserta didik, karena dianggap sebagai mata pelajaran yang paling sulit, sehingga membuat prestasi belajar matematika peserta didik cenderung rendah.

Hal ini selaras dengan pendapat Abdurrahman (2012: 20) yang menyatakan bahwa banyak orang yang memandang matematika sebagai bidang studi yang paling sulit, meskipun demikian semua orang harus mempelajarinya karena merupakan sarana untuk pemecahan masalah kehidupan sehari-hari. Ruseffendi (dalam Heruman, 2014: 1) menjelaskan bahwa matematika adalah bahasa simbol ilmu deduktif yang tidak menerima pembuktian secara deduktif; ilmu tentang keteraturan, dan struktur yang terorganisasi. Matematika merupakan ilmu universal yang di dalamnya meliputi ide, gagasan, dan konsep abstrak yang tidak bisa dilepaskan dari kehidupan manusia sehari-hari. Perkembangan Matematika berbanding lurus dengan 
1046 Efektivitas Model Pembelajaran Problem Based Learning Ditinjau dari Kemampuan Pemecahan Masalah Matematika Siswa di Sekolah Dasar - Bagoes Pradana Sapoetra, Agustina Tyas Asri Hardini

DOI: https://doi.org/10.31004/basicedu.v4i4.503

perkembangan sains dan teknologi Wahyudi \& Siswanti (2015: 26).

Pembelajaran matematika di sekolah dasar harus disesuaikan denngan karakterstik siswa sekolah dasar dan karakteristik pembelajaran matematika. Karakteristik matematika di sekolah dasar yaitu pembelajaran yang bersifat abstrak sedangkan karakteristik siswa di usia sekolah dasar mudah memahami pembelajaran dengan bendabenda kongkrit. Menurut Mulyani (2016: 13) pembelajaran matematika di sekolah dasar tidak mudah untuk dilaksanakan karena karakteristik siswa dan karakteristik matematika di sekolah dasar berbeda. Pembelajaran matematika yang dilaksanakan di sekolah dasar memiliki karakteristik tersendiri, baik dari segi matematika dan karakteristik siswa. Pelaksanaan proses pembelajaran Matematika lebih menekankan pada pemecahan masalah, karena memang pembelajaran matematika sangat erat kaitanya dengan kemampuan pemecahan masalah. Untuk dapat memecahkan suatu permasalahan peserta didik dituntut harus mampu menguasai konsep-konsep matematika.

Berdasarkan hal tersebut, salah satu hal penting untuk dapat memahami konsep-konsep matematika untuk memecahkan suatu masalah adalah pemecahan masalah. Pemecahan masalah berguna untuk menentukan informasi mana yang dapat diterima dan informasi mana yang tidak dapat diterima, sehingga mampu membedakan mana informasi yang dapat dipercaya dan tidak layak dipercaya. Kemampuan pemecahan masalah sangat dibutuhkan dalam kehidupan sehari-hari.
Peserta didik yang sudah dituntut untuk pemecahan masalah diharapkan mampu menjadi generasi yang dapat mengikuti perkembangan zaman yang pesat dengan mampu membedakan mana yang positif dan negatif. Gumantara dkk, (2014: 5) dalam penelitiannya mendefinisikan kemampuan pemecahan masalah merupakan kecakapan atau potensi yang dimiliki siswa dalam menyelesaikan permasalahan dan mengaplikasikan dalam kehidupan sehari-hari. Sedangkan Gumantara dkk, (2014: 4) mengemukakan kemampuan pemecahan masalah dan pemecahan masalah adalah proses yang ditempuh oleh seseorang untuk menyelesaikan masalah yang dihadapinya sampai masalah itu tidak lagi menjadi masalah baginya. Polya (dalam Masbied, 2011: 9) mengartikan pemecahan masalah dan pemecahan masalah sebagai satu usaha mencari jalan keluar dari kesulitan guna mencapai satu tujuan yang tidak begitu mudah segera untuk dicapai.

Selain itu, peserta didik dituntut untuk mampu pemecahan masalah dalam mencari dan menemukan solusi dari permasalahan yang diberikan. Tercapai atau tidaknya tujuan pembelajaran Matematika salah satunya dapat dinilai dari keberhasilan peserta didik dalam menyelesaikan pemasalahan Matematika yang diberikan. Terlebih pada soal cerita yang dikaitkan dengan kehidupan sehari-hari, peserta didik harus mampu memahami permasalahan untuk kemudian mencari penyelesaian dari permasalahan tersebut. Salah satunya terdapat dalam Kompetensi Dasar Matematika kelas IV SD bahwa peserta didik diharapkan mampu memecahkan masalah 
1047 Efektivitas Model Pembelajaran Problem Based Learning Ditinjau dari Kemampuan Pemecahan Masalah Matematika Siswa di Sekolah Dasar - Bagoes Pradana Sapoetra, Agustina Tyas Asri Hardini

DOI: https://doi.org/10.31004/basicedu.v4i4.503

berkaitan dengan keliling dan luas daerah persegi, persegi panjang dan segitiga.

Untuk mendorong keterampilan pemecahan masalah peserta didik dapat digunakan model inovatif dalam pembelajaran yang dapat membantu dalam proses pembelajaran yang komperehensif yang berkaitan dengan berbagai teori pembelajaran modern. Menurut Slameto (2015: 404) model pembelajaran inovatif diantaranya: Reasoning and problem solving, model inquiry training, model based instruction, dan model pembelajaran perubahan koseptual. Model pembelajaran yang dapat digunakan untuk meningkatkan ketrampilan pemecahan masalah adalah model Problem Based Learning. Menurut Slameto (2015: 407) model Problem Based Learning melatih dan mengembangkan kemampuan untuk menyelesaikan masalah yang berorientasi pada masalah otentik dari kehidupan aktual peserta didik, untuk merangsang kemampuan berpikir tingkat tinggi. Dalam model Problem Based Learning berusaha mengajarkan peserta didik dengan masalah, merumuskan masalah dan mencari solusi dalam menyelesaikan masalah. Model pembelajaran ini mengubah pola berpikir peserta didik yang awalnya pembelajaran berpusat pada guru sekarang beralih menjadi berpusat pada peserta didik. Peran guru dalam pembelajaran hanya sebagai fasilitator yaitu hanya sebagai informan sedangkan peserta didik yang terlibat aktif dalam pembelajaran. Model pembelajaran ini menuntut peserta didik agar pemecahan masalah dalam pemecahan masalah.
Langkah-langkah yang tepat juga sangat menentukan keberhasilan suatu model pembelajaan. Penerapan model Problem Based Learning menurut Hosnan (2014: 301) terdiri atas lima langkah utama yang pertama dimulai dari guru memperkenalkan siswa dengan situasi masalah dan akhir dengan penyajian dan analisis hasil kerja siswa: 1) orientasi siswa pada masalah, guru menjelaskan tujuan pembelajaran, menjelaskan logistik yang dibutuhkan, memotivasi agar siswa terlibat pada aktivitas pemecahan masalah yang di pilih, 2) mengorganisasi siswa untuk belajar, guru membantu siswa untuk mendefinisikan dan mengorganisasikan tugas belajar yang berhubungan dengan masalah tersebut, 3) membimbing penyelidikan individual dan kelompok, guru mendorong siswa untuk mengumpulkan informasi yang sesuai, melaksanakan eksperimen untuk mendapatkan penjelasan dan pemecahan masalahnya, 4) mengembangkan dan menyajikan hasil karya, guru membantu siswa untuk merencanakan dan menyiapkan karya yang sesuai, seperti laporan, video, dan model serta membantu berbagai tugas dengan temannya, 5) menganalisis dan mengevaluasi proses pemecahan masalah, guru membantu siswa melakukan refleksi atau evaluasi terhadap penyelidikan dan proses-proses yang mereka gunakan.

Berdasarkan penelitian eksperimen Rohman (2013: 111) yang menggunakan model Matematika realistik dan Problem Based Learning pada Matematika menunjukkan bahwa bahwa hasil pembelajaran matematika realistis dalam prestasi 
1048 Efektivitas Model Pembelajaran Problem Based Learning Ditinjau dari Kemampuan Pemecahan Masalah Matematika Siswa di Sekolah Dasar - Bagoes Pradana Sapoetra, Agustina Tyas Asri Hardini

DOI: https://doi.org/10.31004/basicedu.v4i4.503

belajar sama seperti pembelajaran berbasis masalah, namun baik pembelajaran Matematika realistis maupun hasil pembelajaran yang berbasis masalah dalam prestasi belajar lebih baik daripada pembelajaran konvensional. Ngatiatun (2013) dengan menggunakan model Problem Based Learning terhadap pemecahan masalah Matematika berbentuk soal cerita yang menunjukkan bahwa kemampuan menyelesaikan soal cerita pada pokok bahasan pecahan dengan menggunakan model pembelajaran Problem Based Learning lebih baik daripada menggunakan model pembelajaran konvensional.

Masalah yang sering dihadapi dalam pembelajaran di sekolah dasar terutama pada muatan matematika adalah rendahnya daya serap peserta didik akan konsep matematika. Hal ini dikarenakan mainset peserta didik yang menganggap matematika sebagai ilmu yang susah untuk dipelajari. Hal ini terkait dengan konsep yang disajikan dalam muatan matematika yang bersifat abstrak dan verbal. Masalah rendahnya daya serap peserta didik dalam muatan pelajaran matematika ini harus menjadi perhatian serius, khususnya bagi guru di sekolah. Jika sifat materi matematika yang abstrak, maka guru harus memilih teknik penyajian yang menarik dan strategi pengajaran yang tepat agar materi yang disampaikan mudah dipahami dan tidak membosankan mahasiswa. Berdasarkan hasil pengamatan yang telah dilakukan peneliti, salah satu faktor yang menyebabkan rendahnya hasil belajar peserta didik adalah strategi maupun model pembelajaran yang digunakan oleh dosen. Untuk mengatasi masalah tersebut diperlukan adanya inovasi atau perubahan dalam pembelajaran matematika. Dalam hal ini, pemilihan model pembelajaran Problem Based Learning merupakan salah satu faktor penting dalam meningkatkan kemampuan pemecahan masalah siswa dalam muatan matematika.

\section{METODE}

Penelitian ini, metode penelitian yang digunakan adalah metode Pre Experimental Design. Penelitian ini dilakiikan pada satu kelompok yaitu kelompok eksperimen yang mendapatkan pengajaran dengan menggunakan multimedia berbasis komputer CNC Simulator. Penelitian pada dasarnya adalah usaha pencarian dengan berbagai cara. Tentu saja suatu penelitian membutuhkan suatu metode yang tepat demi tercapainya tujuan dari penelitian. Metode yang digunakan dalam penelitian ini adalah metode penelitian Pre Experimental Design dengan desain penelitian One Group Pretest - Posttest. Dikarenakan pelaksanaan penelitian kelas kontrol sangat sulit, maka hanya digunakan satu kelas saja yaitu kelas eksperimen. Subjek penelitian adalah siswa kelas IV SD Negeri Barukan 2 Tengaran, dengan jumlah siswa 20. Variabel penelitian yang digunakan adalah model Problem Based Learning sebagai variabel bebas dan keterampilan berpikir kritis sebagai variabel terkait.

\section{HASIL DAN PEMBAHASAN}

Pada bagian ini, akan dipaparkan hasil analisis dan data penelitian tentang hasil 
1049 Efektivitas Model Pembelajaran Problem Based Learning Ditinjau dari Kemampuan Pemecahan Masalah Matematika Siswa di Sekolah Dasar - Bagoes Pradana Sapoetra, Agustina Tyas Asri Hardini

DOI: https://doi.org/10.31004/basicedu.v4i4.503

keterampilan pemecahan masalah pada siswa kelas IV di SD N Barukan 2 dengan model Problem Based Learning. Keterampilan pemecahan masalah pada mata pelajaran matematika dari Pre Test. Data pre-test dalam penelitian ini didapat dari tes yang dibeikan berupa tes uraian sejumlah 10 soal tentang materi pecahan. Adapun distribusi frekuensi hasil belajar matematika sebelum dilakukan tindakan adalah sebagai berikut:

Tabel 1 Kemampuan Pemecahan Masalah Siswa pada Pre-Test

\begin{tabular}{llll}
\hline No & $\begin{array}{l}\text { Rentang } \\
\text { Nilai }\end{array}$ & Frekuensi & Persentase \\
\hline 1 & $50-59$ & 2 & $8 \%$ \\
\hline 2 & $60-69$ & 7 & $28 \%$ \\
\hline 3 & $70-79$ & 8 & $32 \%$ \\
\hline 4 & $80-89$ & 6 & $24 \%$ \\
\hline 5 & $90-100$ & 2 & $8 \%$ \\
\hline
\end{tabular}

Berdasarkan tabel di atas madapt diketahui bahwa siswa yang mendapat nilai antara 50-59 berjumlah 2 orang, siswa yang memiliki nilai antara 60-69 berjumlah 7 orang, siswa yang mendapat nilai antara $70-79$ berjumlah 8 orang siswa yang mendapat nilai antara 80-89 terdapat 6 orang dan siswa yang mendapat nilai antara 90100 terdapat 2 orang. Setelah dilakukan pembelajaran model Problem Based Learning untuk mengetahui hasil belajar matmatika, peneliti memberikan tes berupa tes uraian sebanyak 10 soal setelah selesai pembelajaran. Adapun distribusi frekuensi hasil belajar matematika setelah dilakukan tindakan adalah sebagai berikut:
Tabel 2 Kemampuan Pemecahan Masalah Siswa pada Post-Test

\begin{tabular}{cccc}
\hline No & $\begin{array}{l}\text { Rentang } \\
\text { Nilai }\end{array}$ & Frekuensi & Persentase \\
\hline 1 & $60-69$ & 2 & $8 \%$ \\
\hline 2 & $70-79$ & 9 & $36 \%$ \\
\hline 3 & $80-89$ & 8 & $32 \%$ \\
\hline 4 & $90-100$ & 6 & $24 \%$ \\
\hline
\end{tabular}

Berdasarkan tabel di atas dapat diketahui bahwa siswa yang mendapat nilai antara antara 6069 berjumlah 2 orang, siswa yang mendapat nilai antara 70-79 berjumlah 9 orang siswa yang mendapat nilai antara $80-89$ terdapat 8 orang dan siswa yang mendapat nilai antara 90-100 terdapat 6 orang. Rata-rata nilai pre test, nilai terendah dan nilai tertinggi dapat dilihat pada tabel di bawah ini:

\section{Uji Normalitas}

Uji normalitas ini dilakukan dengan menggunakan uji normalitas Kolomogorof Smirnov dengan taraf signifikan >0,05. Berdasarkan hasil analisis uji normalitas dapat dilihat pada tabel 3 berikut:

Tabel 3 Uji Normalitas

One-Sample Kolmogorov-Smirnov Test

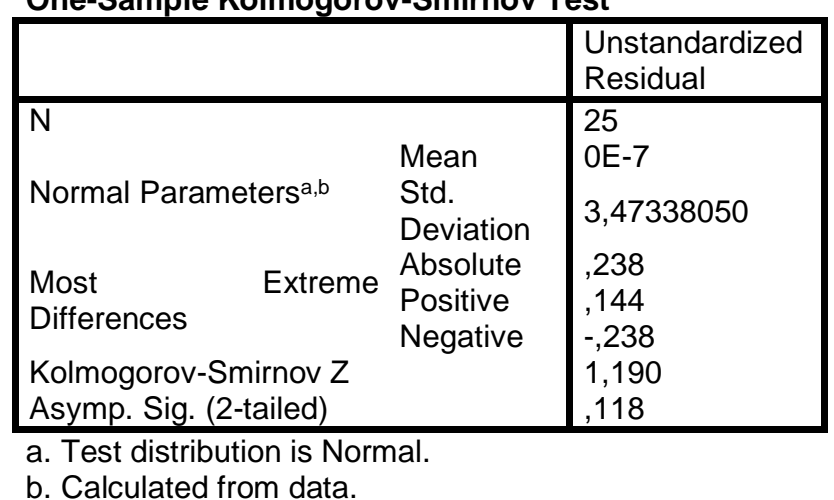


1050 Efektivitas Model Pembelajaran Problem Based Learning Ditinjau dari Kemampuan Pemecahan Masalah Matematika Siswa di Sekolah Dasar - Bagoes Pradana Sapoetra, Agustina Tyas Asri Hardini

DOI: https://doi.org/10.31004/basicedu.v4i4.503

Berdasarkan tabel diatas dapat disimpulkan bahwa data data yang disajikan berkontribusi normal. dengan taraf signifikan 0,118 .

\section{Uji homogenitas.}

Uji homogenitas menggunakan uji homogentas dengan spss dengan taraf signifikan $>0,05$. Berdasarkan hasil analisis Uji homogenitas dapat dilihat pada tabel 4 berikut:

Tabel 4 Uji Homogenitas

Test of Homogeneity of Variances

Hasil Belajar

\begin{tabular}{|c|c|c|c|}
\hline Levene Statistic & df1 & $\mathrm{df} 2$ & Sig. \\
\hline ,003 & 1 & 48 & 955 \\
\hline
\end{tabular}

Berdasarkan tabel diatas dapat disimpulkan bahwa data data yang disajikan berkontribusi homogen. Dengan taraf signifikan 0.955.

\section{Uji Hipotesis}

Uji hipotesis menggunakan uji t untuk dua sampel. Hasil analisis dapat dilihat pada tabel 5 berikut:

Tabel 5 Uji Hipotesis

\begin{tabular}{ccccccc}
\hline $\mathbf{N}$ & $\mathbf{t}$ & $\mathbf{d f}$ & $\begin{array}{c}\text { Sig.(2- } \\
\text { tailed) }\end{array}$ & Md & Std.D & Simpulan \\
\hline 20 & 2,723 & 48 & 0,009 & - & 2,93769 & $\begin{array}{c}\mathrm{H}_{\mathrm{o}} \\
\end{array}$ \\
\hline
\end{tabular}

Data tersebut menjelaskan bahwa dengan jumlah siswa atau $\mathrm{n}=20$ siswa didapatkan Mean of Difference (MD) pada pengujian hipotesis ini sebesar 0,8. Kemudian standar deviasi (SDD) sebesar 48. Untuk standar error (standar kesesatan) dari Mean of difference adalah 2,93769 dan dari hasil perhitungan to $=4,023$ dan bila dikonsultasikan dengan nilai tabel " $t$ " pada taraf signifikansi $5 \%$ dan $\mathrm{df}=\mathrm{N}-1=20-1=19$ pada taraf signifikansi $5 \%$ ttabel $=2,723$. Maka dapat diinterpretasikan, menerima hipotesis alternatif dan menolak hipotesis nol yang berarti bahwa terdapat pengaruh penggunaan problem based learning untuk meningkatkan kemampuan pemecahan masalah.

Berdasarkan hasil analisis pre-test dan posttest menunjukkan bahwa kemampuan pemecahan masalah siswa pada menjadi lebih baik dengan menggunakan model pembelajaran Problem Based Learning pada saat pembelajaran berlangsung dibandingkan dengan nilai pretest yang tidak disertai dengan pemberian treatmen, didapatkan nilai rata-rata pretest sebesar 72,2 sedangkan pada posttest didapatkan nilai rata-rata sebesar 80,2.

Perbedaan nilai akhir antara pretest dan posttest lebih tinggi pada pelaksanaan posttest dibandingkan dengan pretest. Sehingga ada pengaruh yang positif dari penggunaan strategi Problem Based Learning terhadap kemampuan pemecahan masalah siswa pada mata pelajaran matematika Kelas IV SD.

Hal ini sejalan dengan penelitian Sri Giarti (2015) meneliti tentang Peningkatan Keterampilan Proses Pemecahan Masalah, Hasil Belajar Matematika Menggunakan Model Problem Based Learning Terintegrasi Penilaian Autentik pada Siswa kelas VI SDN Bengle, Wonosegoro mengalami peningkatan hal tersebut terlihat bahwa presentase kenaikan keterampilan pemecahan masalah Matematika sebesar 28,54\% untuk siklus 
1051 Efektivitas Model Pembelajaran Problem Based Learning Ditinjau dari Kemampuan Pemecahan Masalah Matematika Siswa di Sekolah Dasar - Bagoes Pradana Sapoetra, Agustina Tyas Asri Hardini

DOI: https://doi.org/10.31004/basicedu.v4i4.503

1 dan $35,46 \%$ untuk siklus 2. Presentase pencapaian (KKM) berikut: pada kondisi awal, presentase pencapaian KKM sebesar 30,77\% (4 siswa), pada siklus 1 presentase meningkat menjadi 53,84\% (7 siswa), dan pada siklus 2 prsentase jumlah siswa yang mencapai KKM meningkat menjadi $84,61 \%$.

\section{SIMPULAN}

Pengaruh penggunaan model pembelajaran Problem Based Learning terhadap peningkatan kemampuan pemecahan masalah siswa di kelas IV. Dilihat dari nilai siswa setelah mendapatkan perlakuan (treatmen), nilai sebelum mendapatkan perlakuan pada pretest dengan nilai rata-rata 72,2 , sedangkan setelah diberikan perlakuan pada nilai posttest siswa mendapatkan nilai rata-rata menjadi 80 ,2. Hal ini menunjukkan bahwa nilai hasil belajar siswa menjadi lebih baik dengan menggunakan pembelajaran Problem Based Learning proses pembelajaran.

Pengujian hipotesis dengan menggunakan uji $t$ untuk dua sampel kecil yang saling berhubungan didapatkan data perhitungan to $=48$ $>2,064=$ ttabel pada signifikansi $0.05=\dagger$. Maka dapat diinterpretasikan bahwa dalam penelitian ini dapat menerima hipotesis alternatif dan menolak hipotesis nol yang dapat disimpulkan bahwa terdapat pengaruh penggunaan model pembelajaran Problem Based Learning.

\section{DAFTAR PUSTAKA}

Abdurrahman, M. (2012). Anak berkesulitan belajar; Teori, diagnosis dan remediasinya.
Depdikbud.

Gumantara, \& Dkk. (2014). Penerapan Model Pembelajaran Problem Based Learning Untuk Meningkatkan Kemampuan Pemecahan Masalah Matematika Siswa Kelas V SD Negeri 2 Sepang. Jurnal Mimbar $P G S D$ Universitas Pendidikan Ganesha Jurusan PGSD, 2(1).

Heruman. (2014). Model Pembelajaran Matematika di Sekolah Dasar. Jakarta: Remaja Rosdakarya.

Hosnan, M. (2014). Pendekatan Saintifik dan Kontekstual dalam Pembelajaran Abad 21. Bogor: Ghalia Indonesia.

Masbied. (2011). Teori Pemecahan Masalah Polya dalam Pembelajaran Matematika. Modul tidak diterbitkan.

Mulyani, S. (2016). Upaya Meningkatkan Hasil Belajar Matematika Melalui Metode Diskusi Berbantuan Media Bagan Peahan di Kelas III SD Kalisari 1. Jurnal Ilmiah PENDIDIKAN DASAR, 3(1), 13 .

Ngatiatun, S. (2013). Pengaruh Model Problem Based Learning terhadap Kemampuan Menyelesaikan Soal Cerita. Jurnal Didaktika Dwija Indria, 3(1).

Rohman, A. (2013). Pendidikan Komparatif. Yogyakarta: Aswaja Presindo.

Sanjaya, A. (2011). Model-model Pembelajaran. Jakarta: Bumi Aksara.

Slameto. (2015). Belajar dan faktor-faktor yang mempengaruhinya. Jakarta: Rineka Cipta.

Wahyudi, \& Siswanti, M. C. (2015). Pengaruh Pendekatan Saintifik melalui Model Discovery Leraning dengan Permainan terhadap Hasil Belajar Matematika Siswa Kelas 5 SD. Scholaria., 5(3), 26. 